\title{
Problems and factors which retard the development and the utilization of groundwater for drinking purposes in the Khartoum state-SUDAN
}

\author{
Yassin Abdelsalam Elhajaz, E. A. Elzein Mohammed and hassab el. Elhadi \\ Faculty of Minerals and Petroleum \\ International University of Africa \\ P. O. Box: 2469, Khartoum- Sudan \\ zein67624@yahoo.com (Correspondancs).
}

\begin{abstract}
The annual municipal water consumption in the Khartoum State is half milliard cubic meters from the River Nile plants and the drilled water supply wells. Sixty percent of this amount is derived from the groundwater sources. Examination of the drilling recorded data of over 2000 wells distributed all over the Khartoum state and enhanced by a review of the previous groundwater studies has indicated that the factors and problems which retarded the best utilization and management of groundwater for drinking water purposes in the state fall into five aspects. These are the geological control, water quality constrain, pollution hazard, technical factors and the absence of groundwater monitoring data. This paper suggests possible solutions, recommendations and mitigations to overcome these problems such as (1)Transfer of water from nearby freshwater sources to villages which lack completely ground water or contain bad quality.(2)Construction of proper sewerage system with proper and adequate and save treatment in order to evade construction of latrine pits and septic tanks which usually result in the pollution of the groundwater reservoirs. (3)Technical Supervision of well drilling specification in the Khartoum state by the concerned ministry. (4) Establishment of a network of monitoring system for the water level and the water quality of groundwater especially near the large diameter and high capacity emergence production wells which were recently drilled in the Khartoum state
\end{abstract}

Keywords-groundwater, development and utilization, Problems, geophysics, e;electricity

\section{INTRODUCTION}

Khartoum State lies over an area of 21950 square kilometers (Fig.1). About 8 million persons live in the Khartoum State. This huge number of people is faced by the problem of providing them with potable water. The ministry of Water Resources and Electricity estimated the need of drinking water as one Millard and 100 million cubic meters in 2010 which will rise to one milliard and 900 million cubic meters in 2020. Unfortunately the present annual consumption of potable water in the State is only half milliard cubic meters (548 million cubic meters) which is derived from the River Nile water plants and Groundwater. However Groundwater constitutes 60 percent of the
Khartoum State annual water consumption. The objective of this study is to provide an account of the

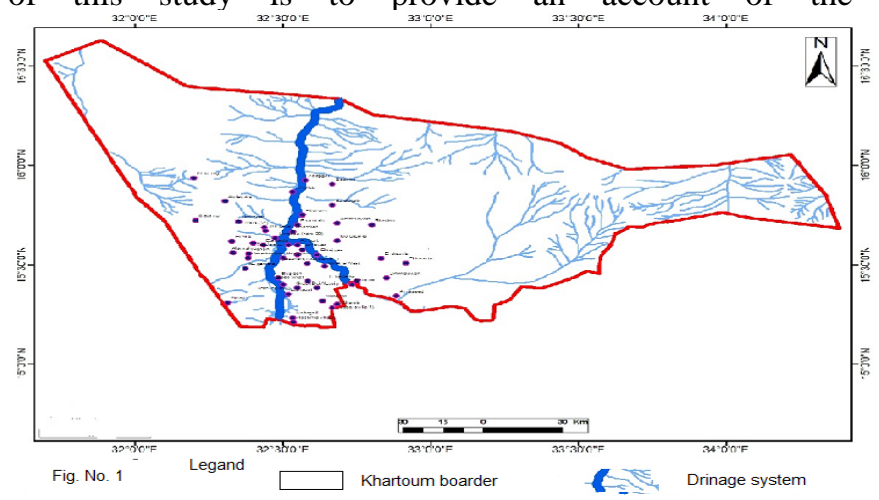

Fig. 1 Location Map of Khartoum State

groundwater resources of the State and to identify the problems which face the best development of groundwater as source of water supply and finally to suggest possible solutions to these problems.

A number of studies of the groundwater resources of the Khartoum State exists ${ }^{[1]}$. They can be classified into Geological and geophysical studies, Groundwater chemistry and hydro-geological studies, Groundwater pollution studies, Water-supply studies and Groundwater management studies.

Which are from the top to the bottom:-1-The windblown sands.2-The alluvial deposits of the Nile and the Wades.3The Gezira formation.4-Basaltic bodies.5-The Nubian Sandstone Formation.6-The Basement Complex. The geophysical studies were directed towards the geological structures of the Basement Complex and its relationship to the Nubian Formation. These studies indicated the presence of a Basaltic intrusive body in the Nubian Formation. The geophysical studies (1985-2010) were concentrated on the evaluation and exploration of groundwater in the Khartoum province.

The previous studies of the groundwater indicate that there are two main aquifers in the Khartoum State, the first and the most important one is located in the Nubian Sandstone formation and the second occurs only in the Gezira Formation which is located in between the two Niles. 
Groundwater occurs in the weakly cemented sandstone beds of the Nubian Formation under confined to semiconfined conditions. This is due to the presence of thick to thin aquitards and aquicludes which are composed of silts and clays. There are two aquifers- the Upper and the Lower aquifers- in the Nubian Formation of Umm Bada Suburb of Umm Dorman town. However it should be pointed out this proposal cannot be applied to the parts of the Khartoum State because there are no thick separating a quicludes to support and justify this classification. The presence of two aquifers in Umm Bada area is a local phenomenon in the Nubian aquifer.

The groundwater level in the Nubian Aquifer varies from 5 to 10 meters below the ground surface near the Niles. However it attains 90 meters in the eastern part of the Khartoum State and becomes more deeper west of the Nile120 meters below the land surface. The movement of groundwater in the Nubian aquifer of the Khartoum State is from the rivers to the east or west of the state. This indicate that the source of recharge are the River Nile and its tributaries.

Groundwater occurs in the sandy and gravely deposits of the Gezira Formation under semi-confined condition because of the presence of the upper clay soils of the Gezira area. The depth to the groundwater of Formation varies from 8 meters below the land surface near the Blue and White Niles and becomes 35 meters at the center of the area between the rivers. Groundwater moves from the rivers to the center of the Gezira area forming a groundwater depression. This has led Saeed [2] to suggest that the source of recharge to the Gezira aquifer is derived from the Blue and the White Niles[2].

The permeability of the Nubian aquifer of the Khartoum State varies from low to moderate (2-15m/day) but in general the permeability is moderate. There is urgent need to analyze the pumping test data and to use statistics to characterize and define the permeability of the upper and the lower parts of the Nubian aquifer.

The yield of drilled wells in the lower parts of the Nubian aquifer with depths of 300 to 400 meters below the ground surface varies from 160 to 540 cubic meters per hour [3].

The yield of wells having a depth of 150metres is low and varies between 15 to 60 cubic meters per hour. However in some places near the rivers the yield of wells is higher about 100 cubic meters per hour.

The previous isotope studies indicate that the river Nile and its tributaries are the sources of recharge to the aquifers in the Khartoum State. Also one of these studies pointed out the effective distance of recharge from the Blue Nile river is 13 kilometers .However monitoring data of the groundwater levels during and after the floods are required to identify the effective recharge distances from the rivers Saeed in1976 estimated the quantity of the annual recharge from the Nile to a distance of one kilometer east and west of the river Nile as 100 million cubic meters. Unfortunately
Saeed did not mention whether this quantity which represents the bank storage returns back to the river after the flood or travels away from the river. Hence we suggest that there urgent need for continuous annual monitoring data for the groundwater levels.

It is estimated that the total groundwater storage in the Nubian aquifer of the Khartoum State to a depth of 150 meter from the land surface as 77 milliard cubic meters in addition to 8 milliard cubic meters in the Gezira Formation.

Farah[4] evaluated the total groundwater as 950 milliard cubic meters, 835 milliard cubic meters in the lower parts of the aquifer and 115milliard cubic meters in the Upper parts[4]. Recently Bader eldin[3] estimated the total groundwater storage in the lower parts of the Nubian aquifer as 32 milliard cubic meters[5]. This variation in the estimates is due the lack of the correct and precise value of the saturated thickness of the Nubian aquifer. This needs extensive work on the subsurface geophysical logging of the water supply wells.

\section{THE GROUNDWATER CHEMISTRY}

The Nubian aquifer of the Khartoum State is generally characterized by a good water quality which has a low total dissolved solids (200-450 mgliter).The high salinity(1000$2900 \mathrm{mg} \backslash$ liter) is located in Gadden and Jebel El Toriya area. The high salinity of the groundwater is due to the presence of the Basaltic body's impermeable layers and the thick mudstone layers.

The high salinity in the groundwater of the Nubian aquifer of Sheikh E 1 Amin (Total dissolved solids of 2000$5000 \mathrm{mg}$ liter) is attributed to the presence of paleo-Sebkhas or salty lakes which were formed during the Pleistocene or Quaternary times[6].

The Gezira Formation aquifer in Soba area is characterized by a high salinity (the total dissolved solids varies between 1000 and 3000 mglliter). This salinity is linked with the Paeo-Sebkha and the closed lakes in which the salts and the evaporates accumulated[5].

The Nubian aquifer of the Khartoum State is generally characterized by a good water quality which has a low total dissolved solids(200-450mgliter) (Fig.4). The high salinity(1000-2900 mg \liter) is located in Gadden and Jebel El Toriya area. The high salinity of the groundwater is due to the presence of the Basaltic body's impermeable layers and the thick mudstone layers.

The high salinity in the groundwater of the Nubian aquifer of Sheikh E 1 Amin (Total dissolved solids of 2000$5000 \mathrm{mg}$ liter) is attributed to the presence of paleo-Sebkhas or salty lakes which were formed during the Pleistocene or Quaternary times[6].

The Gezira Formation aquifer in Soba area is characterized by a high salinity(the total dissolved solids varies between 1000 and 3000 mglliter). This salinity is linked with the Paeo-Sebkha and the closed lakes in which the salts and the evaporates accumulated[5] 


\section{Material AND MethodS}

The study area is shown in figure no.1. It lies in the Arid zones area which is characterized by erratic and variable annual rainfall from one year to another. The amount of rainfall depend on the movement of the Intertropical convergence zone which separates the dry wind from the moist winds. In the Khartoum State the InterTropical Convergence Zone (ITCZ) moves northward in July and August. South of the ITCZ the origin of the moist wind is the Indian or Atlantic oceans which result in rainfall. About 75 percent of the rainfall occurs during the July and August months. The rainfall is associated with thunderstorms. It varies from $100 \mathrm{~mm}$ in the north of the Khartoum State to200mm in the south. During 1988 the rainfall was exceptionally high $420 \mathrm{~mm}$ but in 1982 the annual rainfall was very low only $4 \mathrm{~mm}$. According to Abu Sin[4] there are dry periods in the Khartoum Province (1965-1984) as well as humid periods (1920-1939)[1].This pattern indicates cyclic changes in the weather shown by the low and high rainfall every twenty years due to global climatic changes Abu Sin op. cited also noticed that the driest years in The Khartoum State occurred during the years 1983 and 1986 This is due to increase of urbanization and the removal of plants and trees

The highest temperature occurs in the months of May and June (37 degrees). The lowest temperature (6 degrees) occurs in the winter times(December). The average air humidity varies between 22 and 29\%.

The State of Khartoum is characterized by the presence of deserts vegetation. Acacia and Tortilis trees grow along the water courses and the Wadies. Panicum grass and Haskanit also grow. Sunut, Sayal and Talih trees grow near the river Nile and its tributaries. The following table shows type of soils and their distribution in the Khartoum State

TABLE I.HOWS TYPE OF SOILS AND THEIR DISTRIBUTION IN THE KHARTOUM STATE

\begin{tabular}{|c|c|}
\hline Type of soil & Percentage over the total area of the state \\
\hline Xersols & 65 \\
\hline Vetisols & 10 \\
\hline Fl sols & 20 \\
\hline Regosols & 5 \\
\hline
\end{tabular}

The Xerosls represents the soils of arid dry regions and this is the most dominant soil in the Khartoum State. This soil contain a very small percent of organic matter. The xerosol soil results from the weathering processes of rocks and sediment. The vertisol which occur in between the Niles in the southern part of the State is the same type of the black cotton soils of the Gezira which is characterized by desiccation cracks and fractures and contains calcareous nodules. The Fluviosoils are mainly located along the river Nile and its tributaries. They contain a high percent of organic matter and are considered the most fertile soil in the Khartoum State. The Regosols are windblown deposit of Qoz Abu Dulu. These sandy soils are moderate fertile soils which are characterized by high permeability and contain a small amount of salts.

\section{Discussion AND CONCLUSIONS}

The methods employed in this study included the examination of the drilling data of over 2000 water supply wells which are homogeneously distributed over the Khartoum State. The data is composed of lithological well logs, well pumping data, geophysical borehole logging, Engineering design and well construction data and the chemical quality analyses of the drilled wells. This was supported and enhanced by the review of the previous studies and reports of the groundwater of the Khartoum State.

The followings conclusions were obtained by using the data of 2000 drilled water supply wells in the Khartoum State aided by a thorough review of the previous groundwater studies(1)Geological aspect. The presence of the impermeable Basement Complex rocks in north and north east of the State and west of the White Nile resulted in either dry wells or low yields which do not cover the needs of the local population.(2)Water quality aspect. The State contains three regions with groundwater which is not fit for human consumption Gadeen and Jebel El Toriya west of the White Nile Hatab area east of the Nile river.(3)Pollution of the shallow groundwater (Nubian or the Gezira aquifers) by septic tanks and latrines.(4)Technical aspect. Incorrect well design and selection of inappropriate and suitable water pumps.(5)High abstraction rates from the large diameter and deep water supply wells which can lead to the depletion of the non-renewable and fossil groundwater of the Nubian aquifer which represents the main source of the water supply in the Khartoum State.

\section{REFERENCES}

[1] Abu Sin M.E. and Devies HRJ 1991 The future of Sudan Capital region. A study of the development and changes . Khartoum University press.

[2] Saeed E.M. ( 1976 ) Hydro geology of Khartoum province and geology and mineral resources department . Bulletin No.29 pp( 138$)$.

[3] Bader eldin M. MO. ( 2010 ) Hydro geological and hydro chemical characteristics of the lower part of the Nubian sandstone Aquifer in Khartoum state. Unpublished Msc. Thesis University of Khartoum.

[4] Farah E.A. Abduelatif, kheir O.and Barazi N.( 1997 ) Hydrological investigations to evaluate the groundwater resources in the northern part of Khartoum basin. Journal of African Earth Sceince vol.25 No. pp $453-466$.

[5] El Boushi I.M. ( 1972 ) the shallow groundwater of the Gezera formation at Khartoum and the Northern Gezira Sudan Notes and records vol.53pp154-163

[6] Hagaz Y.A. and Kheir Allah M. 1988 Pale hydrology of the Nubian Aquifer northeast of the Blue Nile near Khartoum Sudan Journal of hydrology vol.97 pp 117-125 Elsevier Hollan 